\title{
Anthropomorphic Images at the Padjelanta Site, Northern Sweden \\ Rock Engravings in the Context of Sámi Myth and Ritual
}

\author{
Inga-Maria Mulk \& Tim Bayliss-Smith
}

\begin{abstract}
The paper discusses three phases of scratched images from the Padjelanta site of Sámi rock art in Laponia, northern Sweden. Pre-dating the middle phase of Viking Age/Medieval period sailing boats is a set of stylised anthopomorphs. These early images resemble certain petroglyphs from Alta, goddess motifs on Sámi drums, and the Earth Mother figure in the Mandasj myths. Possible ritual contexts for the Padjelanta images are discussed, including autumn reindeer hunting, human burials, and smallscale quarrying for asbestos and soapstone. As a tentative hypothesis, a link between the early anthropomorphs and the Sámi goddess Máttaráhkká is proposed.

Inga-Maria Mulk, Ajtte Swedish Mountain and Sámi Museum, Box 116 . SE-962 23 Jokkmokk, Sweden.

Tim Bayliss-Smith, Department of Geography, University of Cambridge. Cambridge CB2 3EN, England.
\end{abstract}

Key words: Sámi, rock art, Padjelanta, Laponia, ritual, myth, Máttaráhkká, shamanism, quarrying, soapstone.

\section{THE PADJELANTA SITE}

\section{Introduction}

The rock engravings at what has been called the Padjelanta site were discovered in 1990 by members of Sirkas sameby, a Sámi reindeer herding society based in Jokkmokk community. Padjelanta, meaning 'the upper level', is the traditional summer grazing area for the Mountain Sámi in the Lule river valley (Figure 1). It is a high plateau region, located west of the Sarek mountains and within the Laponia World Heritage Area. The local vegetation is an alpine tundra classified as grass heath, about 67 degrees North latitude and at altitudes between 700 and $800 \mathrm{~m}$. This is a harsh and difficult environment with snow cover for 7-8 months of the year, but in late summer it offers good reindeer pasture and some opportunities for fishing arctic char in the lakes. The valley where the site is located has been used as summer grazing by reindeer pastoralists in recent centuries, and the site itself was used probably up until the $17^{\text {th }}$ century AD for soapstone quarrying. On panels adjacent to the quarried rock faces there are scratched figures, some indecipherable but others recognisable as boats, reindeer and 
Fig. 1. Position of the Padjelanta site: (A) within the territories of the inland Sámi sijdda, as reconstructed by Hultblad (1968:72) from tax records for the late $16^{\text {th }}$ century; $(B)$ within the Laponia World Heritage Area today; and (C) in its local setting. showing the division of the southfacing rock face into four zones.

human-like figures. All these images are faint and are partly obscured by moss and lichen, and the rock face itself may be hidden beneath snowdrifts for much of the year. When melting snow or rain wets the surface, all but the most deeply incised figures are almost invisible.

We have so far reported on the six boat figures recorded up to 1998 , of which three are

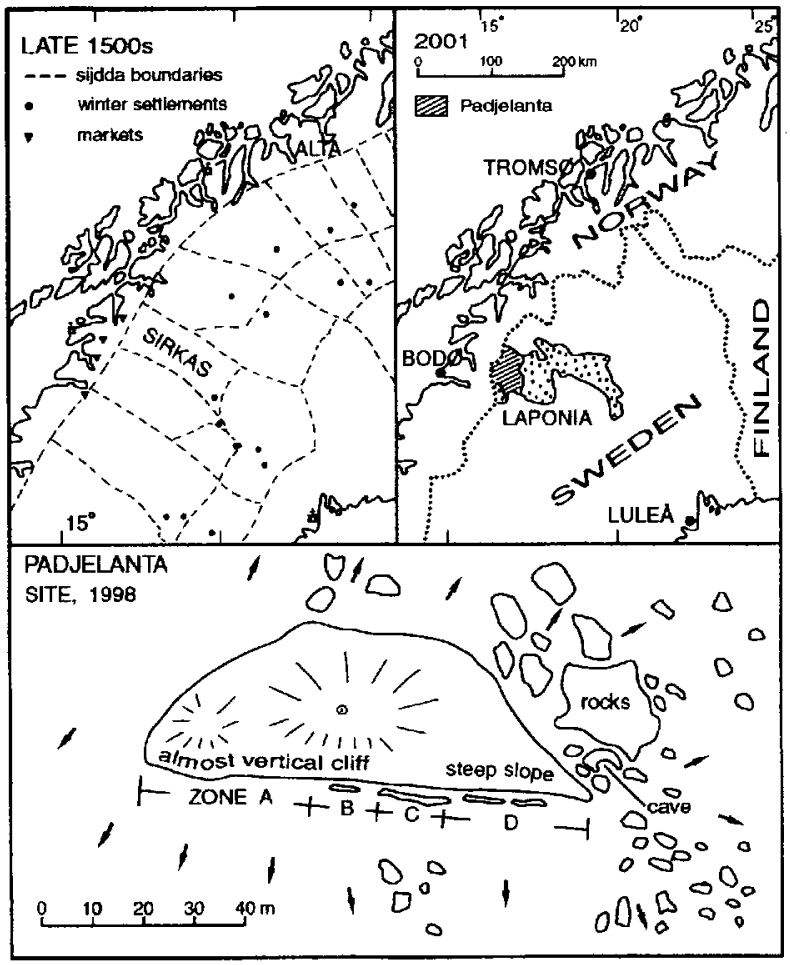

large sailing boats. In 1999 the image of a seventh boat was discovered, only partly preserved but similar in form. The sailing boats resemble the type of boat used in the fjords of north Norway during the Viking Age between 800 and 1300 AD (Mulk 1998; Bayliss-Smith \& Mulk 1998, 1999). Overlain by the boat pictures there is an earlier phase of engravings, of unknown age but possibly pre-dating the Nordic Iron Age. These earlier engravings all depict anthropomorphs, and they have not previously been reported. In this paper we present details of all of the anthropomorphic images at the Padjelanta site, and we offer an interpretation based on the relationships between iconography, mythology and ritual practices in Sámi hunting society. As a context for this analysis we first explore the wider interactions of the Sámi with outsiders, and particularly with the neighbouring populations on the north Norway coast.

\section{Padjelanta in the context of Sámi/Nordic interaction}

Our knowledge of the prehistory of the last 2000 years suggests that the rock engravings at Padjelanta were produced by local Sámi from Sirkas sijdda (Mulk 1994a). (All spellings of Sámi words in this paper follow the orthography of the Lule Sámi language). From at least the Iron Age and prior to the onset of reindeer pastoralism in the $16^{\text {th }}$ century AD, the Sámi hunting groups (sijdda) living in the interior of northern Sweden traded furs eastwards with Coastal Sámi living around the Gulf of Bothnia. They also maintained exchange relations westwards with the Coastal Sámi who lived in the fjords of north Norway (Mulk 1994a). 
In North Norway after the $3^{\text {rd }}$ century AD Nordic settlement spread into the outer fjords that had potential farmland and also land route connections that facilitated trade with the Sámi (Vorren et al. 1990; Moe 1991; Storli 2000). However in many areas, including the small fjords leading from Tysfjord which are the ones nearest to the Padjelanta site, the inner zone remained the territory of the Coastal Sami (Hansen 1990). These people were not only "fishers and bird-catchers and hunters" as recorded in Ottar's account of about 880-890 (Lund 1984: 19), but also middlemen in trade and boatbuilding. The Coastal Sámi exploited their control of the pine forests of the inner fjords to become expert boatbuilders, making clinker-built boats for customers among the farming communities (Kolsrud 1961; Westerdahl 1987; Nielssen 1990; Borgos \& Torgvaer 1998).

During the period in which the boat images were produced, c. $800-1300 \mathrm{AD}$, the Sámi living in the inland were still operating as mobile hunter-fisher-gatherers, engaging also in the fur trade, and moving to the mountains in late summer mainly for wild reindeer hunting. There are many hunting pit systems in this region dating from this period, while the stallo sites, which were used by Sámi hunters as base camps, have occupation dates that range from 600 to 1400 and peak in the $11^{\text {th }}$ and $12^{\text {th }}$ centuries (Mulk 1994a:141, 166). The period 1000-1300 was also important for the deposition of coins and other metal objects in sacrificial sites, which reflects the wealth that the Sámi were receiving at this time from their participation in the medieval fur trade (Serning 1956; Mulk 1996; Mulk \& Bayliss-Smith, in press).

Large sailing boats existed on the north Norway coast after the $8^{\text {th }}$ century, but it does not seem likely that such boats were used by the inland Sami. For them an opportunity to see such boats was during visits to the Norwegian coast. Many features of the large coastal trading boats of the period c. 800-1300, including sails, rigging, side rudder, dinghy (eptirbatr, Old Norse), and anchor, are faithfully reproduced in the Padjelanta rock art. There is a clear resemblance between these images and boats of the knarr type. However, it seems unlikely that the Padjelanta boat pictures were intended merely to be scale models (icons, in the semiotic sense) of Viking Age sailing ships. We believe that these images, alongside other aspects of Sámi culture like spoken or sung myths and performed rituals, were intended as signs (in the semiotic sense) to convey a range of coded messages about the divine powers. Elsewhere we have pointed to the way that boats are used in Sámi cosmology as a symbol, the boat representing the transport of the soul to an afterlife, and also serving as a metaphor for the voyaging of the shaman and his helpers in trance to the spirit world. These semiotic connections were first recorded in Historia Norvegiae (c. 1 190), and they are shown on Sámi drums of the $17^{\text {th }}$ century onwards (Rydving 1993; DuBois 1999: 130; Bayliss-Smith \& Mulk 1999:22ff).

We believe also that the rock engravings at Padjelanta commemorate particular visits by Sámi groups for ritual sacrifices associated with hunting or quarrying. It is possible also that the images indicate a special entry point to the underworld. In these ways, we shall argue, the images conveyed indexical meanings to the participants in seasonal rituals and to later visitors, and so helped to confirm beliefs about certain 
religious ideas. By seeing the rock art as a way for the Sámi to signify these various meanings, we hope to show how the Padjelanta site reflects the changing ways in which aspects of their world-view were being coded before, during and after the Viking Age and Medieval periods.

Icon, index and symbol

In order to establish a language for exploring the encoded messages in rock art, we have found it helpful to adopt the approach of Peircian semiotics. We have referred above to a strong iconic resemblance between the Padjelanta boats and the knarr type of sailing boat, and to the likelihood that these images were also used by the Sámi as symbols and as indices. These terms relate to the semiotics of Charles Sanders Peirce, who showed that to be an effective medium of communication, any 'language' - whether actions, words or images - requires three kinds of sign (Burks 1949:676). These signs Peirce called the icon, the index and the symbol. In social anthropology his approach was used by Firth (1973) to analyse ritual, and by Tambiah (1979) and Rappaport (1979) as a way to explore the meaning of Thai Buddhist ceremonies and New Guinea religious rites, respectively. More recently Peircian semiotics has been employed extensively by Rappaport (1999:66, 462) for constructing a general theory of religious ritual. The same concepts form a basis for Deacon's (1997) analysis of how human language has evolved. We think it worthwhile to adopt this approach to the Padjelanta rock art, and we therefore make a logical separation between the iconic, the indexical and the symbolic ways that these images might have conveyed meaning. Following Raymond Firth we can define and illustrate these terms as follows:

"An index ... [is] a sign directly related in fact to what it signifies. If a hunter in pursuit of a lion sees a certain kind of footprint in the sand, this is an index to the passage of his game.... An icon is a sign that represents its object by resembling it.... We might regard the statue of a lion as iconic by virtue of it having its form and proportions determined by those of the animal. A symbol ... [is] a sign determined by its object only in the sense that it will be so interpreted, an allocation dependent on habit, convention or agreement, or natural disposition of the interpreter. Following our example, a lion is a symbol of bravery by convention" (Firth 1973:61).

Contrary to Jungian assumptions, there are no 'natural symbols'. The lion might symbolise bravery in one culture, but other cultures will have different conventions. For the San of southern Africa, rock paintings that show lions are referring to the outof-body experiences of shamans who are journeying while in a state of trance (LewisWilliams 1985).

Iconic similarity may be straightforward to interpret, but to understand the indexical and symbolic meanings of an image we need to try and make explicit its context in time and space. An image that is perceived in context takes on fuller meanings, just as a warning sign becomes truly meaningful only if seen in the context of a road and a dangerous corner. Therefore, over and above the iconic meanings that rock engravings might convey, each one should also be considered as an index which signals that a 
particular rock face had special significance, or was visited at a particular time, or was memorable in a particular ritual context. As a symbol, the same image that serves as icon and index may also be a sign with an agreed meaning, perhaps representing something which does not exist in visible form. For example, an image serving as a symbol may help to channel the cosmic forces which, participants believe, are likely to be potent in the particular ritual context in which that image has been made, or in which it is shown.

For a modern Western audience all of these statements would be obvious if the image in question were a Christian cross. We are familiar with this image, and we are aware of its origin as an iconic depiction of the crucifiction of Jesus Christ. In its simplified form, we know it as a sign that symbolises Christianity itself. If the cross marks a special place (e.g. a rock face) we might guess that it is intended to indicate a place of Christian worship or a site of Christian burial. As icon, symbol and index, the cross conveys multiple meanings to all persons who have some degree of semiotic competence, and who inherit the same set of cultural meanings. We believe that rock art images should be analysed in the same way, as signs that were intended to convey multiple meanings.

For the Padjelanta images, by examining the nature of the relationship between sign and object we hope to go beyond the simple question of iconic meaning ('What does the image depict?'), and to ask new questions about the relationship between image and locality, image and ritual, and image and symbolic association. There is a clear resemblance between most of the images at Padjelanta and some object in the real world (boats, humans, animals), but this fact should not divert us from seeking other meanings.

\section{Fieldwork at the site}

A fieldwork programme was carried out at the Padjelanta site by Ájtte Museum, Jokkmokk, in 1992, 1993, 1998 and 1999. Despite the logistic problems presented by the site, we are confident that almost all the rock engravings that are both visible and recognisable have now been recorded, and reconnaissance surveys of archaeological sites in the vicinity have also been made (Mulk et al. 2001). It has proved impossible so far to photograph the rock engravings in a way which fully reveals their detail. Therefore in recording them the main technique used was the direct tracing of the pictures on to transparent paper and plastic. The soapstone rock surface is soft and fragile, so no attempt has been made to clean it or mark it in any way. Some areas of the rock are partially obscured by the growth of lichen, and if cleaned some further details might be revealed. No sub-surface archaeological work has been carried out at the site.

A sketch map of the rock outcrop itself is shown in Figure 1. An almost vertical cliff rises $22-27 \mathrm{~m}$ to a summit that gives extensive views across the valley to the south. The summit is accessible from the north side via a more gentle slope. The southfacing rock face extends $92 \mathrm{~m}$ from west to east, and for convenience can be divided into four zones (Table 1). 


\begin{tabular}{llll}
\hline Zone & Distance from west & Description & Phase of the rock art \\
\hline $\mathrm{A}$ & $0-34 \mathrm{~m}$ & Natural rock & No engravings \\
$\mathrm{B}$ & $34-48 \mathrm{~m}$ & Asbestos quarries & Assumed to be Phase 1 \\
$\mathrm{C}$ & $48-60.5 \mathrm{~m}$ & Soapstone quarries & Phase 3 \\
$\mathrm{D}$ & $60.5-92 \mathrm{~m}$ & Natural rock with local quarrying & Phase 1 and Phase 2 \\
\hline
\end{tabular}

Table I. The south-facing cliff at the Padjelanta rock art site, showing its division into zones.

Zone A. The western section is Zone A (length $34 \mathrm{~m}$ ), which appears to be an entirely natural rock face. No anthropogenic features have been found on the surface of the rock, which is dark in colour, weathered and lichen-covered.

Zone $B$. There is evidence of asbestos quarrying activity at the western end of Zone B (length $14 \mathrm{~m}$ ), with quarry marks visible especially on fallen blocks at the base of the cliff. On these blocks are many scratches that may be anthropogenic but are indecipherable apart from four small human figures. Images in this zone have been numbered B1-B6.

Zone $C$. Outcrops of soapstone in Zone C (length $12.5 \mathrm{~m}$ ) have been freshly-exposed along a $3 \mathrm{~m}$ section where there are a few graffiti from the 1990s and an engraved date ' $1673 . \mathrm{Vl}$ '. All of this recently quarried surface shows fresh chisel marks. The rock is pale grey in colour and has less than 1 per cent lichen cover. In addition there is a $5 \mathrm{~m}$ stretch at the eastern end of the zone with earlier quarrying, as shown by its darker, more weathered surface and by the few colonies of small lichens. If we disregard tool marks and seemingly random or accidental scratches, there are eight small anthopogenic images found within Zone $\mathrm{C}$, numbered $\mathrm{Cl}-\mathrm{C} 8$.

Zone $D$. The most easterly section of cliff is Zone D (length $31.5 \mathrm{~m}$ ), where there is a large number of scratched images resembling boats, animals and humans especially on a $4 \mathrm{~m}$ face of smooth vertical soapstone towards the eastern end of the zone. At least 25 distinct images can be distinguished, numbered D1-D25. Somewhat later soapstone quarrying has cut away the western margin of the engraved panel, destroying part of one boat. All of the rock surface in Zone D has a black weathered surface which is usually wet, with a patchy cover of mosses, lichens and liverworts.

Graves. About $5 \mathrm{~m}$ eastwards of the rock face that constitutes Zone $\mathrm{D}$ there is a scattering of large boulders which form a small cave-like rock shelter. According to Tomas Partapuoli (born 1930), a member of Sirkas sameby who has been herding his reindeer in the Padjelanta region all his life, this rock shelter once contained evidence for human graves. He remembered (in 1999) that old people had told him when he was a young man that they had seen traces of bones and birchbark beneath this overhang. Today there are no remaining signs of Sámi graves and no excavations have been attempted, so we cannot estimate the age and number of burials.

In the sections that follow we first describe the human-like figures that are contemporary with the seven boat images, six of which we have already reported (Bayliss-Smith \& Mulk 1999). The figures in this paper are based on a close re-examination of the field evidence in 1999, when we recorded all scratches on the rock that became visible 
during dry sunny conditions and with the benefit of a magnifying glass. In this paper we therefore have omitted some natural cracks in the rock that were mistakenly shown as part of the scratched image in previous publications (Mulk 1998; Bayliss-Smith \& Mulk 1998; 1999).

Following this analysis of the boat-phase human figures we then describe some much fainter and more elusive anthropomorphs, some of them first seen and recorded in 1999, which, we believe, pre-date the boats and associated images. Finally we discuss the meaning of these figures through an analysis of the seasonal economy of Sámi hunting society, the rituals which we believe took place during visits to the Padjelanta site, and Sami myths which we think may throw light on the identity of the anthropomorphs in Zone B and Zone D.

\section{HUMAN FIGURES AND ANTHROPOMORPHS AT PADJELANTA}

We can divide the human-like figures (anthropomorphs) at Padjelanta into three phases, according to both style and provenance. At least one deeply engraved figure (a naked woman) belongs to recent times, and is probably contemporary with the period of soapstone quarrying when a scratched date ('1673 VI') appears on the freshest of the rock exposures in Zone C. Other human figures in a different style are found in close association with the boats in Zone $\mathrm{D}$, and can therefore can be dated with reasonable confidence to the period 800-1300 AD (Bayliss-Smith \& Mulk 1999). Thirdly, there is a category of anthropomorphic figures which we believe date from an earlier phase.

\section{Phase 3 (Early Modern/Modern): miscellaneous graffiti}

Soapstone quarrying in Zone C can be approximately dated by the date ' 1673 VI' cut with a knife blade or chisel on a quarried surface. In this zone there are other engravings which we can categorise as recent graffiti. New information from Sirkas sameby (pers. comm., 1999) indicates that one of these images, a reindeer calf-marking diagram, was cut into the rock at the same time as the most recent date ('1990'). The only human figure dating from Phase 3 is the outline of a fat, naked woman (C6, shown in Bayliss-Smith \& Mulk 1999:36). As it is cut into the newly-quarried surface of Zone $\mathrm{C}$ we believe that $\mathrm{C} 6$ must date from the last 350 years and possibly from the $20^{\text {th }}$ century. Its intended meaning as a humorous and erotic image would appear to be selfevident.

\section{Phase 2 (Viking Age/Medieval): boats, animals and humans}

Spread across a panel measuring $2.5 \mathrm{~m}$ long and $0.5 \mathrm{~m}$ high in Zone D are the outlined images of seven boats with associated humans, reindeer and possibly other animals. The figures have been scratched probably with an iron knife or a nail, producing clean lines incised up to $1 \mathrm{~mm}$ into the soapstone. The images seem to be drawn by different hands, and are on both quarried and unquarried soapstone. The rock surfaces all appear to be much older than those of Phase 3 , being darkened by weathering and having algae, liverworts and about 10 per cent lichen cover (Table 2 and Figure 2).

The boats vary considerably in size and detail, and the best preserved examples 


\begin{tabular}{llll}
\hline Phase & Technique & Code & Description \\
\hline 3 & Carved outline & C6 & Nude woman \\
2 & Incised outline & D15 & Shaman/hunter in between Boats D13 and D17 \\
2 & Incised outline & D17 & Human in the stem of Boat D17 \\
2 & Incised outline & D17 & Human in the stern of Boat D17 \\
2 & Incised outline & D20a & Male human \\
2 & Incised outline & D20b & Female human \\
2 & Incised outline & D23 & Incomplete human \\
1 & Scratched figures & B4 & Four anthropo-morphs, one with staff, two with hats \\
1 & Carved outline & D27 & Head of anthropomorph \\
1 & Scratched figure & D26 & Part of head of anthropomorph \\
1 & Scratched figure & D8 & Large anthropomorph \\
1 & Scratched figure & D14 & Large anthropomorph \\
1 & Scratched figure & D18 & Anthropomorph \\
1 & Scratched figure & D19 & Face with 'sun-beams' radiating \\
\hline
\end{tabular}

Table 2. Humans and anthropomorphs at the Padjelanta rock art site: a complete list. ('Code' refers to the inventory of Padjelanta figures in Mulk et al. 2001)

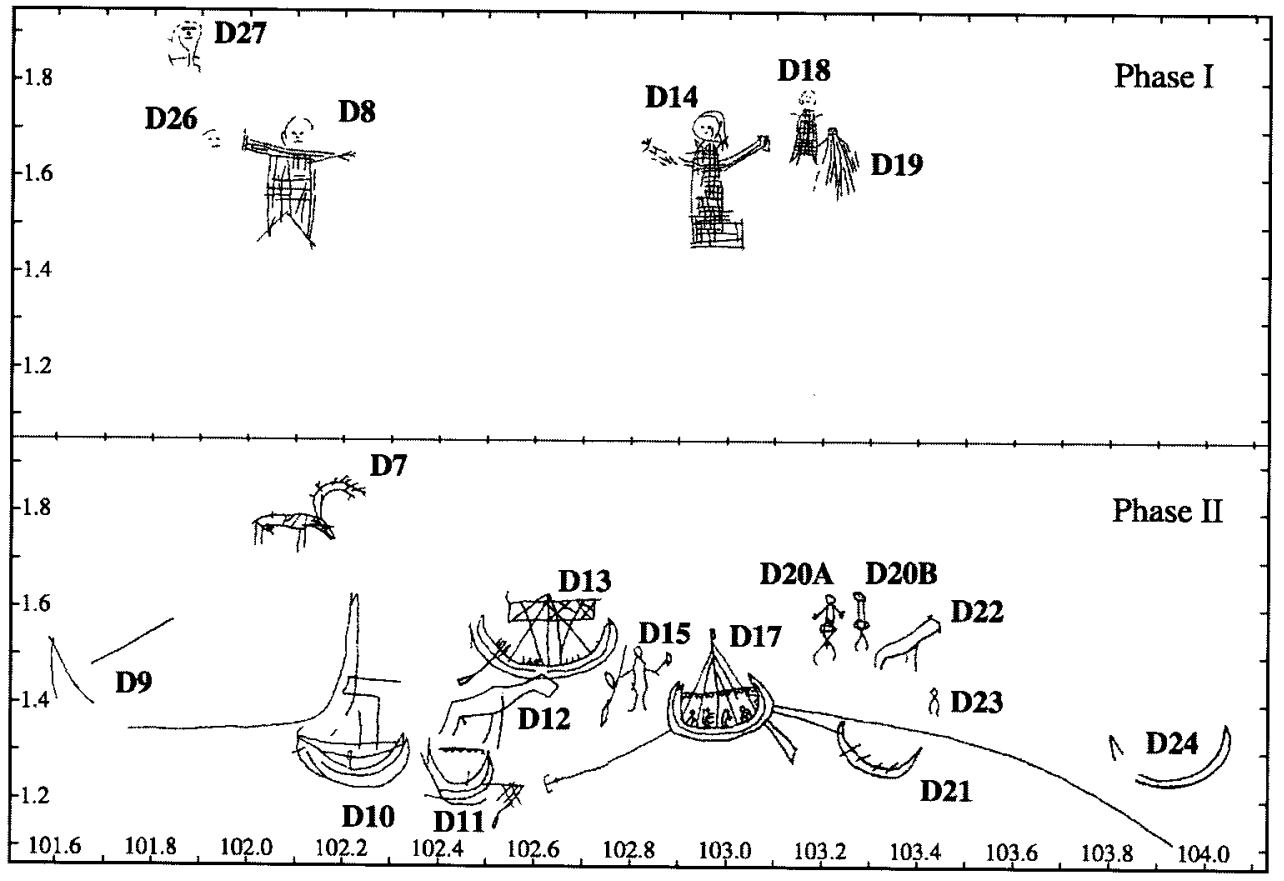

Fig. 2. Co-ordinates and relative positions of rock-art in Zone D at Padjelanta, showing the anthropomorphs of Phase 1 and the boats, humans and animal figures of Phase 2.

show a number of details which enable them to be approximately dated. These features include clinker-built hulls, high stern and stem posts, masts and sails, rigging, and in two cases side rudders. One sailing boat is connected to a smaller dinghy which has oars, and also has a line attached to an anchor of the familiar iron type with shank and arms. We interpret these images as representing coastal trading boats of the knarr 


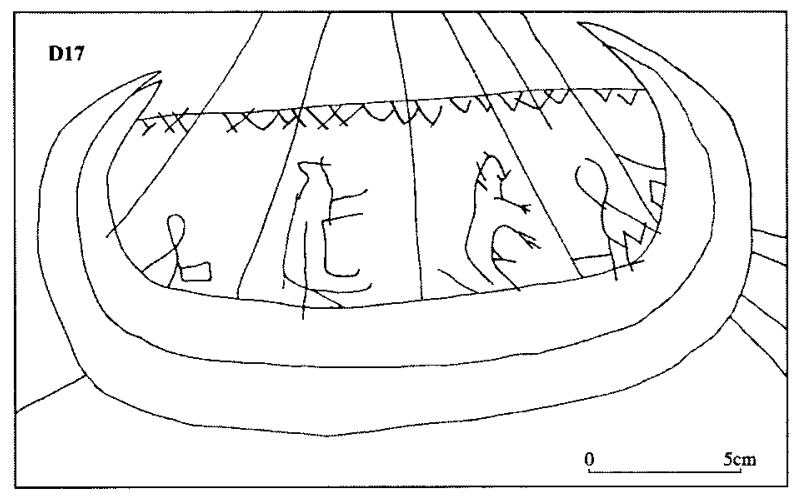

Fig. 3. A boat (DI7) of Phase 2, with iconic detail (anchor; side rudder, rigging, sail, etc.) indicating that the boat is a coastal trader (knarr tope) from the period c. 800-1300 AD. The boat contains four occupants that may be iconic depictions (two persons. two animals), or may be intended to symbolise the spirits of the dead or shamanic soul joumeys while in a state of trance.

type, which did not exist on the north Norway coast until after 800 AD at the earliest, and which were superceded by boats with stern rudders after 1300. This type of boat would have been familiar to those Inland Sámi who had travelled to the coast, for example to visit the autumn market at Grunnfjord in Tysfjord (Bayliss-Smith \& Mulk 1999). Associated with these boats there are altogether five human figures.

Two human figures are an integral part of one of the sailing boats (Figure 3). Boat D17 has inside its hull four occupants. The two figures in the middle look more like animals and the two at each end look more like humans. The right-hand human figure, at the stern, appears to be operating the long steering oar which hangs down on the starboard (hidden) side of the boat. The left-hand figure is highly schematic but appears to have a human head. Like the animals, he or she is facing the stern.

The animals are more clearly depicted than the humans, but are equally ambiguous in terms of their iconic meaning. The left-hand one has two short ears or horns and might be a cow, sheep or reindeer calf. A vertical line connects its body to the hull of the boat, perhaps showing it to be tethered. The other animal has a penis, two ears, three 'claws' on each of two front legs, and possibly traces of a collar, and it might be a dog or a wolverine. Both 'animals' are sitting as if they were humans, rather than standing on four legs like animals, so they should perhaps be thought of as 'therianthropes', creatures having both animal and human attributes.

Elsewhere on this boat panel, not physically connected to any of the boats but in a style which matches them, there are three other human figures (Figure 4). One, of uncertain sex, is a tall figure (D15) standing between two of the sailing boats (D13 and D17). He (possibly she) is drawn face-on and with rather accurate proportions, holding a paddle or perhaps a hoop net to the left, and what may be a bow or a drum to the right. Either a bow or a drum could be the identifying insignia of a Sámi shaman (noajdde). As with the two human-like occupants of boat D17 no attempt has been made to depict a face within the shape of the head, but given the tiny space available this would be technically difficult in any case. It is possible that the artist depicting this figure had in mind some narrative which connected this shaman/hunter with the three adjacent boats (D13, D17, D21).

Another two figures (D20A, D20B), one clearly a man and the other probably a 


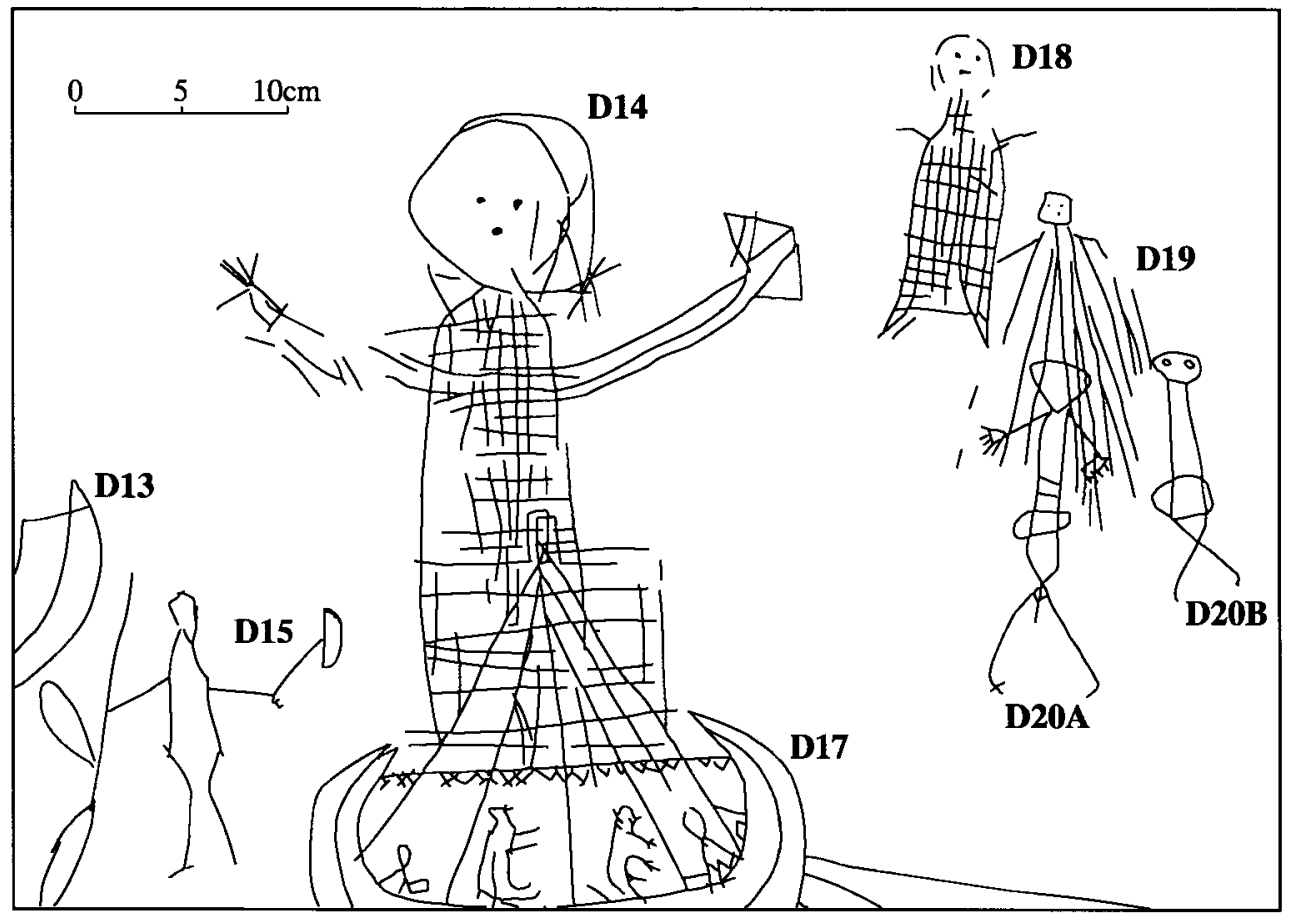

Fig. 4. Five of the Phase 2 human figures: D15 (shaman/hunter), DI7 (two boat occupants). D20A (man) and D2OB (?woman). Figures D17 and D20A are superpositioned, possibly not deliberately, over earlier Phase 1 figures, the anthropomorphs D14 and D19.

woman, stand between and somewhat above boat D13 and boat D21 (see Figure 4). However these two figures are somewhat separate from the boats, and they may not have any narrative connection to them. Instead there may be a connection with the zoomorph D22 which is probably a reindeer (shown in Figure 2). The two humans seem, from a modern perpective, to be depicted in a naive style. The male (D20A) has arms sticking out from the angle of the body and head, with five fingers on each hand. The body is encircled by a belt. Between the stick-like legs are male genitalia, and these are defined in the same way as on a reindeer (D7) that is on the same rock panel but some distance away (see Figure 5). On the 'female' figure (D20B) no arms are depicted, or none have survived, but the head has two tiny eyes scratched out as oval circles. The male figure is scratched on top of some of the lines that radiate out of an earlier anthropomorph. As this earlier figure is more shallowly incised into the rock and today at least is almost invisible when the rock surface is wet, it is not clear if the superimposition was deliberate or accidental.

At a similar height to the human D20A but $1.2 \mathrm{~m}$ to the left there is a reindeer engraving (D7) which appears to be contemporary with the seven boats and occupants and the associated human figures (D15, D20A, D20B). This unquestionable reindeer is depicted as a male animal and appears to have a harness and pack saddle (Figure 5). It is interpreted as one of the tamed reindeer that were used in Sámi hunting society as 


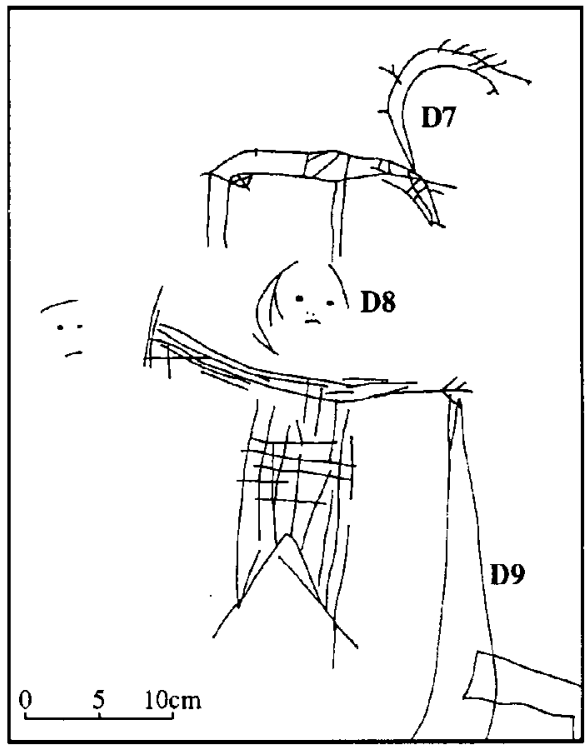

Fig. 5. Two Phase 2 images, a male reindeer (D7) with saddle and harness, and the stem or stern of a boat (D9); these are superimposed over two earlier Phase I anthropomorphs, one almost complete (D8) and the other fragmentary (D26).

pack animals, for pulling sledges or carrying cargo. The fact that the Sámi owned many tamed reindeer at this time is clearly indicated in Ottar's account of 880-890 (Lund 1984).

The incised mode of execution of this reindeer and the way its male genitalia are depicted associate it strongly with the male figure already described (D20A), although the wide separation between these two figures makes it difficult for them to be seen as part of the same 'picture'. The only other human figure which we regard as contemporary with the boat figures is an isolated pair of 'human' legs (D23). These legs (shown in Figure 2) are similar to those of the female in D20B (Figure 3). D23 has no obvious narrative connection to another image, and it may be incomplete or a fragment of a picture that has not survived.

\section{Phase 1 (Late Stone Age - Early Iron Age?): anthropomorphs}

The third category of human figures was the last to be recognised in the field, because of their faint and ephemoral nature. These figures are fully visible as shallow grey scratches only when the rock is dry and sunlit, at which point the superimposed nature of some of the images becomes apparent (e.g. in Figure 4). When the rock is wet they become practically invisible, and for this reason we cannot be certain that the artists of the boats, reindeer and human figures already described were aware of earlier anthropomorphs on the rock surfaces when they superimposed the new images. For example was it deliberate or accidental that the sailing boat with four occupants (D17) was placed on top of the lower body of the large anthropomorph D14 (see Figure 4)? Is it by chance that another boat (D9) is touched by the outstretched hand of the large anthropomorph D8, or that the reindeer (D7) is juxtaposed immediately above its head (see Figure 5)? One could speculate that if these various images were simultaneously visible, then the superpositioning or juxtapositioning was designed to convey symbolic meanings (cf. Lewis-Williams 1981:11). However, today under normal (i.e. wet or frozen) conditions the very existence of the earlier images is usually unsuspected by an observer.

The early-phase anthropomorphs are engraved on the soapstone with wide, shallow scratches, in contrast to the sharp lines of the boat-phase engravings, and it seems unlikely that a metal tool was used in their formation. A stick or sharp piece of bone or antler is more probable. As with the boat pictures and associated humans, parts of the 
early-phase images are obscured by algae and lichen. However, it did not prove possible in the field to demonstrate any difference in the relative age of phases through measurements of lichen size or per-cent cover, as the patchiness of lichen growth seems to be mainly a response to micro-scale variations in surface texture and wetness.

Altogether ten figures of early anthropomorphs have been recorded, of which three or four are mere fragments. The largest (D8) measures $30 \mathrm{~cm}$ tall and is $27 \mathrm{~cm}$ wide along its outstretched arms, while the smallest (B4) measures $7 \mathrm{~cm}$ and $5.5 \mathrm{~cm}$ in the same dimensions. All except D19 are standing and facing outwards, their full figures suggesting perhaps that they are female. The eyes and mouth are defined by small holes in the rock, probably pits produced by percussion. In the case of D8 two tiny nostrils define the nose, and the mouth is a down-turned scratch giving the figure a rather fierce expression. Seven of the ten figures have vertical and horizontal crosshatching defining the body, which might be intended to convey some kind of clothing. The most complete figure in B4 has a short staff in its right hand and a long staff in its left (Figure 6). A short staff is also held in the right hand of D8, while its left hand has fingers. Both hands of D14 are also defined by fingers. The one figure which has a different style is D19, with a square rather than round head and with no body. Instead D19 has about fifteen trailing lines radiating beneath, not unlike modern representations of sunbeams.

One, perhaps two of the four tiny figures in B4 are unique in having tassels on top of a headpiece, not unlike a Sámi hat of the recent period (see Figure 6). These four figures are all located in Zone B where we find traces of asbestos quarrying. Asbestos was used as a temper in ceramic production during the Bronze Age and Early Iron Age

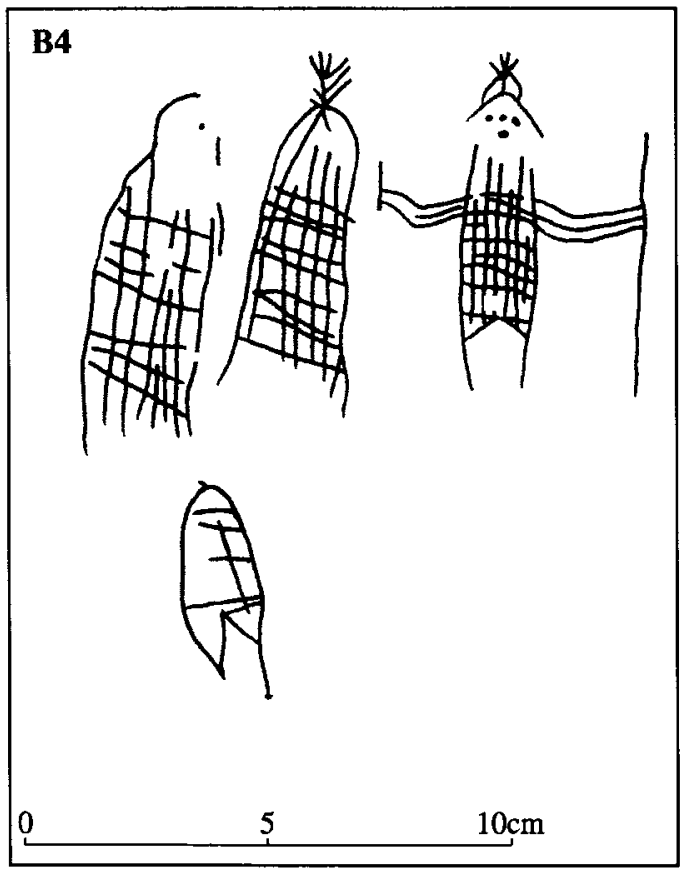
(1800 BC-400 AD), which raises the possibility that all these Phase 1 anthropomorphs are much older than the boats and other figures of Phase 2 .

\section{POSITIONING OF THE PADJE- LANTA FIGURES}

As a first approach to a discussion of the meaning of the Padjelanta images, we consider first of all their positions in relation to each other. In his classic account of San rock art in southern Africa, Lewis-Williams (1981:10) suggests that an analysis of positioning should consider four possibilities.

Fig. 6. Four anthropomorphs (B4) assumed to be of Phase 1 age, from the zone of asbestos quarrying (Zone B). 
$i$. The positioning of images as an activity group depends upon the assumption that the rock art is merely telling a story. The images form a set of iconic representations of a scene, and were intended as no more than a scale model of an actual event, real (remembered) or imagined (constructed). At the Padjelanta site it is possible that the three boats (D13, D17, D21) linked by the human figure D15 ('the shaman/hunter') may be an activity group intended to depict an actual event - although we believe it more likely that the scene utilises icons like boats for an indexical or symbolic purpose.

ii. As in the case of an activity group, with juxtapositioning the artist is using images as icons. However, by putting together representations of different things which do not co-exist either in nature or in the context of human activities, a different meaning is being conveyed (Lewis-Williams 1981:10). Juxtapositioning is an effective way for an artist to make symbolic statements, whether in rock art or in modern advertising. An example of the latter is the picture of a Viking boat on a bottle of 'Explorer Vodka' (a popular Swedish brand), which juxtaposes a symbol of adventure, courage and national pride with an alcoholic drink. The fact that vodka did not exist in northern Europe in Viking times does not prevent the picture from conveying a potent symbolic message to consumers.

Juxtapositioning may well be present within D17, although this sailing boat could also be interpreted as an activity group of related icons, such as the clinker-built hull, mast, sail, long side rudder, large iron anchor, and attached dinghy. These are the characteristic features which enable us today - and would have enabled a Sámi audience in the period c. $800-1300 \mathrm{AD}$ - to identify the boat as a coastal trader (knarr) from the fjords of north Norway. However, it seems likely that the artist has gone beyond the iconic mode of representation by placing inside the boat four occupants, thereby juxtapositioning the familiar (two humans, two animals) with the exotic (a sailing boat). In this way the boat could convey a symbolic message about the way in which these figures (perhaps two known persons, a dog and a young reindeer) were being carried into a supernatural dimension.

iii. Superpositioning is the third mode, but here we cannot identify cases at Padjelanta with confidence because of uncertainties about the visibility of the early-phase images when the later, boat-phase engravings were made. In the case of San rock art, LewisWilliams (1981:11) has shown that "superpositioning was not, as had previously been supposed, always the result of a random disregard for the work of predecessors, but might sometimes have been a means of linking paintings that was governed by definite conventions". At Padjelanta, the partial superpositioning of the male figure D20A over the anthropomorph D19 might be a case in point. A second possibility is the superpositioning of the sailing boat D17 over the earlier and larger image of anthropomorph D19 (see Figure 4). As with juxtapositioning, the individual forms may be iconic but the act of superpositioning makes a statement about the relationship between two contrasted icons, which are thereby linked to create symbolic meanings.

$i v$. In the fourth mode of position, conflation, the iconic form of representation virtually disappears. What is depicted does not resemble something in nature, but instead is constructed by combining elements of one icon with elements of another. In 
this way the artist is able to suggest an analogy between them, as with the elandheaded and hoofed humans of San rock paintings (Lewis-Williams 1981:22,65). The rainbow serpent in Australian Aboriginal rock art provides another example. Rainbow serpents are "composite beings made up of key elements from a number of different creatures including plants" (Tacon et al. 1996:120). There are also many conflated motifs on Sámi drums, for example on Drum 44 first recorded in 1689. One of its motifs is a human figure standing on top of a reindeer, which is interpreted as a conflation signifying Atjek (Diermes, Horagalles) the god of thunder (Manker 1950:3567). To adopt instead the literal view, that this image is actually an activity group (a man balancing on an animal's back), is to deny to the artists of the past the symbolic dimension of thought which dominated most forms of pictorial representation until the age of photography.

Highly stylised conflations can end up as pure symbols, motifs whose original meanings are almost lost through repetition and abstraction. Only persons with a high degree of symbolic competence (e.g. priests, shamans) can decode the symbol for an audience, and remind them of its origin as a conflation of iconic images. A man nailed to a cross provides a good example from Christian symbolism. We believe that the early anthropomorphic images at Padjelanta should also be interpreted as conflated symbols, and that these images were used by the Sámi to represent the cosmic powers.

\section{COSMIC AND HISTORICAL CONCEPTIONS OF THE WORLD}

The anthropomorphs of Phase 1, the earliest phase, are the most repetitive of the motifs present at Padjelanta. These tall standing figures stare out of the rock face, gazing southwards, arms outstretched, with cross-hatched bodies. They vary in size, but with one exception (D19) the form is the same, even though the details are not in every case depicted, or have not survived. By comparison the seven boats of Phase 2 are a highly diverse set of images, each boat depicted individually and differently, while the humans and zoomorphs of this phase are also varied.

In the case of these cross-hatched anthropomorphs we seem to be glimpsing a cosmic concept in the form of a conflated image. These are not icons that, despite symbolic connotations, are primarily intended to have a clear resemblance to some model in the real world. Instead we are reminded of some of the motifs on Sámi drums, and there are parallels too in the repetitive images that are commonly found in the art of other hunter-gatherer groups. We are reminded of the Aborigines' rainbow serpents, the eland-human conflation of the San, and the characteristic motifs of pre-European rock art in North America. On the Great Plains, for example, Klassen (1998, citing Vastokas 1990), discusses the 'Ceremonial' phase of Blackfoot rock art which encompasses the period c. 250-1725 AD. At this time, the Plains Indians were producing what Klassen calls 'iconic' imagery (in the terms used in this paper, 'iconic images' should be called 'symbolic images formed from conflated or juxtaposed icons'):

"In formal terms, iconic images can be defined as static, frontal, symmetrical, noninteractive motifs, found alone or in small juxtaposed groups... Indications of narrative or 'time-sequence' relationships are not apparent, ... and they do not 
represent a specific time, place or event, but rather evoke the eternal present of the spirit world. Iconic images can be recognised as presentations of sacred subjectmatter and themes, such as the objects and beings associated with visions and medicine powers" (Klassen 1998:44-45).

The 'cosmic' conception of the world, which this art reflects, began to be challenged in the Great Plains by the direct and indirect effects of European contact in the $18^{\text {th }}$ century. Klassen traces a series of changes in the rock art following the introduction of horses, then guns, and finally colonisation. A transition took place in the images, whether on rock surfaces, clothing or tipis, from a 'symbolic' (Klassen's 'iconic') towards a 'narrative' style. Before the coming of Europeans the pictures consisted of isolated, repetitive motifs (animals, weapons, humans), which are interpreted as icons carrying symbolic meanings (Klassen 1998:45). After European contact we see in the art many of the same motifs as before, but also some new ones (e.g. horses, guns). These are combined to create narratives that seem intended to represent actual people and real events.

At the same time we can infer a substantial degree of cultural continuity among Plains Indians from the continued depiction in their art of traditional motifs like the shield. The $19^{\text {th }}$ century ethnography shows that the shield functioned symbolically as an object invested with supernatural powers to protect its owner in battle (Klassen 1998:47). Such meanings were not at first affected by European contact. It was only at a later stage in North America that the 'cosmic' conception of the world was replaced by an entirely 'historical' view.

A further example of this transition is provided by the Micmac Indians of Nova Scotia (Molyneaux 1987). After the Micmac became Christians and totally dependent on the fur trade, their rock art begins to portray specific objects and events in Micmac life (horses, soldiers, ships, names and dates). These replace the images of animals such as moose which were metaphors for spiritual relationships within the old cosmic, non-historical world-view (Molyneaux 1987:197-9). In Scotland a similar process of transition has been proposed by O'Meadhra (1993) for Pictish art. After the demise of the 'symbol stones' (conflations of both iconic and symbolic images), Pictish artists produced more varied images that include sketches of Viking ships. O'Meadhra (1993:424) suggests that this change marks a transition in the intensity of contact between eastern Scotland and the literate outside world.

At Padjelanta the transition from the repetitive cross-hatched anthropomorphs to the diverse images of boats, animals and humans that characterise the Viking Age/ Medieval period can be interpreted in the same way. With Nordic colonisation on the coasts of north Norway and the intensification of the fur trade after $800 \mathrm{AD}$, new contacts enabled the Sámi to incorporate a new kind of boat into their pictures. It is not that the cosmology of Sámi hunting society was transformed - that process was not finally accomplished until the $17^{\text {th }}$ century when Lutheran missionaries imposed Christianity on the Sámi. Rather, the images made by the Sámi around 1000 AD began to include new ways of visualising old symbols.

Therefore what we are seeing at Padjelanta in Phase 2 is a particular example of the 
general process discussed by Thomas DuBois, "a dynamic process of religious exchange operating in the Viking Age in which individual ritual elements - and sometimes even practitioners - crossed cultural and economic lines, becoming reinscribed within the world-view of the recipient community" (DuBois 1999:137). Rituals carried out by the Sámi at sacrificial sites in the $11^{\text {th }}-14^{\text {th }}$ centuries seem to reflect their adoption of the religious symbols of outsiders, in the context of intensive fur trade contacts (Zachrisson 1987). We have discussed elsewhere alternative ways in which the sailing boats can be interpreted, as new icons to convey old symbolic ideas connected to shamanism and the afterlife (Bayliss-Smith \& Mulk 1999: 21-25). In the remainder of this paper we turn to the earlier images at Padjelanta, termed here cross-hatched anthropomorphs. In what contexts were Sámi cosmic ideas transformed into these images, and what exactly might the images represent?

\section{CONTEXTS OF COSMIC DEPICTION AT PADJELANTA}

The actual positions of the cross-hatched anthropomorphs on the rock do not help us to decipher their meaning, as they appear to be isolated, repetitive motifs. To appreciate how the Padjelanta site might have been used by Sámi hunting society we must therefore consider the site's wider context. Its location, above $700 \mathrm{~m}$ altitude in the sub-Arctic tundra zone, in a windswept valley many kilometres distant from the nearest forest or Atlantic fjord, and snow-covered from November to June, suggests that visits to the area are most likely to have taken place between mid-summer and early autumn. We can consider the likely reasons for such visits under three headings:

- reindeer hunting and associated rituals;

- human burials and associated rituals; and/or

- quarrying of asbestos and soapstone, and associated rituals.

In each case it is likely that visits were relatively infrequent. There was no guarantee that more than one or two persons in a group using the site would ever return there in future. Rowlands (1993) has argued that in such circumstances the transmission of an accurate memory of a place would have needed reinforcement in one of two ways. One was to create memories through acts that left no lasting physical trace behind them, such as the deposition of valuables, the performance of rituals, and the naming of places. Another way was to construct monuments which commemorated particular people, events and places, and which made sites permanently significant even after their original meaning was no longer understood. Bradley (2000) has shown how monuments gradually replaced memories of natural places in the farming cultures in post-Neolithic Europe.

We suggest that the smooth soapstone surfaces available at the Padjelanta site made it possible for the Sámi to commemorate the site's meaning through rock art. In this way they were able to achieve a kind of 'monumental' reinforcement of memory, a response which might have been unnecessary had the site been more accessible and therefore more frequently visited. But what kind of commemoration did the Phase 1 anthropomorphs achieve? If the images were intended to symbolise a god or goddess, 
then to identify the deity we need to consider the religious beliefs associated with the three activities, hunting, burials and quarrying.

\section{i. Autumn hunting rituals}

The reindeer move up to the mountain pastures in late June and stay there until September, and before the onset of pastoralism (c. 1600 AD) the animals were hunted during their autumn migration eastwards back to the boreal forests. Archaeological surveys of the Padjelanta region have revealed a number of occupation sites from prepastoralist times, a few dating back to the Stone Age. However, sites from the Iron Age, Viking Age and Medieval periods are the most common, in particular the stallo settlement sites and associated hunting pit systems (Mulk 1994a). Today numerous reindeer tracks pass by the Padjelanta site, and before c. 1600 the valley was undoubtedly visited by hunters of the wild reindeer in late summer or early autumn. Is it possible that the Padjelanta site was the focal point for religious rituals connected to reindeer hunting?

Historical evidence for rituals associated with reindeer slaughter comes from the reindeer herding society of more recent centuries. However, despite the transition from hunting to herding the basic structure of Sámi religion probably remained unchanged, at least in terms of hunting rituals, animal ceremonialism and the basic structures of shamanism (Hultkrantz 1965, 1985). Pastoralism did not alter the basic beliefs about life after death, and the Sámi continued to carry out autumn rituals including sacrifices to the gods who had influence on the well-being of the herds (Mebius 1965; 1968:76; Westman 1997).

In Lule Lappmark these rituals continued until at least the 1670s, and the offerings often included tame animals that had been obtained by trade in north Norway, such as horses, oxen, sheep and goats (Rydving 1993:105). In the historical period some sources indicate there was an iconographic element to these rituals. For example Sigvard Kildal, writing in 1730 , mentions that, as well as using the usual places of sacrifice, the Sámi would often "erect a great many pictures, figures and carved logs and sticks, right in among the boulders" (translated by Rydving 1993:105). At an earlier period, especially in the $11^{\text {th }}-13^{\text {th }}$ centuries AD, the offerings often included arrowheads, jewellery and silver coins (Serning 1956; Mulk \& Bayliss-Smith, in press).

We conclude that Padjelanta would have been a suitable place for seasonal rituals associated with the deities connected to hunting, for example Átjek, Juoksákká, Liejbbålmáj and Biejvve. Could the anthropomorphic images represent the cosmic power that was symbolised by one of these deities?

\section{ii. Ceremonial practice and burials}

The oral history which suggests Sámi graves once existed very close to the Padjelanta boat images has already been mentioned. A symbolic association between boats and the spirits of the dead was prominent in Sámi religious belief, so the juxtaposition between graves and boat images is suggestive, although not conclusive. It is tempting to associate each of the boats with a particular burial event, and the earlier anthro- 
pomorphs might have had similar meanings.

The landscape around the Padjelanta site is also highly suggestive of a link to Sámi religious ritual. Above the rock faces which were quarried and engraved in prehistory is a small hill top which provides an impressive viewpoint across the valley and towards the south. Neither ethnographic nor archaeological evidence can provide support, but the topography and aspect of this hill top would make it very suitable as a sacrificial site for offerings to the goddess of Mother Earth Máttaráhkká, or to her in her other role as Jábmeáhkká, the goddess ruling the underworld.

A possible parallel is provided by the mountain peak at Aldon, on the north side of Varanger fjord in east Finnmark, which was still being used by the Sámi as a sacrificial site until it was desecrated by a Norwegian missionary in 1718. As at Padjelanta, there are south-facing rock faces on Aldon engraved with human figures, reindeer and a sailing ship (Simonsen 1969:16-19; 1970:184-5; 1979:481-2). Sámi ritual sites that are combined with burial places exist elsewhere, for example at Mortensnes $14 \mathrm{~km}$ west of Aldon. Mortensnes comprises more than 200 graves around a ring-shaped sacrificial site, the graves spanning the period c. 1000-1800 (Kleppe 1974; K. Schanche 1988; A. Schanche 1997:173).

If Padjelanta were another of these focal points in a sacred landscape, then it would have been used for sacrificial offerings during occasional visits. The smooth, southfacing rock surface should itself be seen as a liminal place where access could be gained to the underworld. Perhaps the anthropomorphic figures (and later the boats and associated humans) were marked on the rock to signify the spirits of dead persons in the world beneath?

\section{iii. Rituals connected to quarrying}

A third possible context for the Padjelanta rock engravings is suggested by the importance of the site for quarrying asbestos and soapstone. According to this model, while reindeer hunting was an activity of the wider region, it was these particular resources that motivated visits to the actual site. In earlier times, before c. $400 \mathrm{AD}$, the procurement of asbestos focussed on a $14 \mathrm{~m}$ long outcrop (Zone B) which shows traces of quarrying. It is in this zone that, in addition to many random-looking scratches, we find the group of four small cross-hatched anthropomorphs (see Figure 6), although we cannot prove that asbestos quarrying and these images are contemporary.

Soapstone has also been quarried at Padjelanta, mainly along a $12.5 \mathrm{~m}$ length of rock face in Zone $\mathrm{C}$. This activity dates from the Early Modern period to judge from the ' 1673 ' graffito and the fresh appearance of the rock surface. Soapstone quarrying also occurred at an earlier phase in the western half of Zone D, where a dark, weathered, algae- and lichen-colonised surface with chisel marks abuts on to (and partly destroys) the outline of the seventh boat (D9).

Historical sources do not reveal what rituals accompanied the procurement of raw materials such as soapstone, but a link to Máttaráhkká seems very possible. According to Sámi traditional belief stone was thought to be alive, in the same way as a person or an animal. There is a parallel belief among the Chukchi of eastern Siberia, where stone 
was regarded as part of the body of Mother Earth, and where stone artefacts that were broken were returned to the earth, to a place given the same name as the domain of the ancestors (Eidlitz Kuoljok 1999:122f). Might the cross-hatched anthropomorphs at Padjelanta have been ritual images which commemorated episodes of soapstone or asbestos quarrying?

\section{Which cosmic power?}

Unfortunately neither the direct evidence (iconographic, archaeological and historical), nor the inferences we can make from the context of the site, provide us with any firm basis for identifying the anthropomorphs depicted at the Padjelanta site. We have identified three possible contexts for rituals: reindeer hunting, burials, and quarrying. Each activity provides a plausible context for the depiction of images, but a number of different Sámi deities could be implicated. We are not in a position to provide a firm identification of the anthropomorphs, but to push the discussion forward we present a hypothesis based on Máttaráhkká and Mandasj, both key symbols in Sámi myth and ritual.

\section{INTERPRETING ROCK ART THROUGH MYTHS AND RITUALS}

\section{The mutual reinforcement of myths, rituals and icons}

Where knowledge is not mediated through science, nor transmitted by an educated elite, nor reinforced with the authority of texts, beliefs about reality are communicated in other ways. Stories, songs, pictures and performances are the usual ways in which beliefs are coded, so that meanings can be more easily communicated to others. These semiotic practices are common to all non-literate societies, and their manifestations can be classified into things spoken or sung (myths), things seen (images), and things done (rituals). In practice the three activities are virtually inseparable.

Many scholars have argued that what we call 'religion' has its origin not in the abstract beliefs that myths express and images depict, but rather in the ritualised activities that cement the bonds of community. According to Edward Tylor (1871, cited by Bell 1997:4), "the myth was derived from the ritual, and not the ritual from the myth; for the ritual was fixed and the myth was variable, the ritual was obligatory and faith in the myth was at the discretion of the worshipper". Therefore, it has been argued, to understand a myth or an image we first need to determine the ritual that accompanied it. Others have disagreed, seeing the ritual as dependent on beliefs, ideas and symbols rather than vice-versa (e.g. Eliade 1963). Nonetheless there is general agreement that in traditional societies the myth (as a metaphor) and the image (as a symbol) were never regarded as things separate from their ritual context.

\section{Giving expression to the transcendent}

It is through the combined media of myths, images and rituals that the transcendent aspects of reality can be given a symbolic (rather than a literal) form of expression (Rappaport 1999). A symbolic form of expression makes abstract ideas - ideas which are not empirically verifiable - much more convincing, as well as more memorable, 
even enjoyable, for the participants in rituals or for an audience. This 'audience' might be the young who are being initiated by older people, or it might be those persons less able to 'see' into other worlds, who are being informed by another person who is more competent, a so-called clever-man, medicine-man or shaman (in Sámi, noajdde).

In this way myths can play an important role in the transmission of knowledge. A myth conveys a coded message by offering to listeners an entertaining story, a poetic language, and concepts that are expressed through a series of linked metaphors. These devices enable story-telling to give meaning to people's lives, by explaining what is happening to them now in the context of what happened in ancient times. Myths often focus on the creation of life throught the intervention of cosmic forces. Such beliefs not only explain the origins of the present, they also offer a promise of life-creation in the future. In this way the myth constitutes a mirror that tells people who they are, how they should behave, and how the future can be safeguarded (Bell 1997:5ff; Rappaport 1999:164).

Although myths can help to explain the origins and meanings of birth, life and death, it is in ritual performance that such beliefs are reinforced in powerful and persuasive ways. Important events in the life cycle of an individual are normally marked by a group ritual, and this involves a performance in which there are formal acts and utterances. Some of the meanings in these rituals are encoded by the participants, while other meanings are inherited from tradition. Persons participating in rituals signal by their performance an acceptance of beliefs which they might otherwise find obscure or easy to contradict (Rappaport 1999:23ff, 134-5). Rituals can therefore help to validate ideas about the mythical past, about divine reality, and about earthly events in the present and future.

\section{The role of images}

Images will often play an important role in these rituals, contributing to the 'canonical' stream of information which participants find already encoded as part of an unchanging liturgy. Rappaport (1999:54-58) characterises this type of information as spiritual, conceptual or abstract in nature. It needs to be conveyed primarily in symbols, and it provides the aspects of belief that are durable, invariant and inherited from tradition. As well as symbols ritual also includes 'self-referential' information, which consists of indexical messages that the participants themselves encode through the particular acts and utterances that they feel are appropriate to the occasion, such as chanting, praying, kneeling, eating or drinking. Rappaport (1999:58) points out that in all kinds of ritual the canonical and the self-referential messages are dependent on each other for their overall effectiveness - neither would be so convincing to participants if each was conveyed in isolation.

Alongside messages that are recited, sung or acted out in various ways, there is a role in liturgy for purely visual messages which can reinforce the meaning of the acts and utterances in powerful ways. Special clothing, particular hair styles and body decoration are often important signifiers (Tambiah 1979; Lewis-Williams 1981). It is the symbolic associations they invoke which make images an effective way to commu- 
nicate abstract ideas. In the case of the Padjelanta Phase 2 engravings, perhaps the Sámi could recognise in a familiar object (e.g. a boat) a metaphor that represented an intangible aspect of the divine world (e.g. soul journeys). In this way people could use the image to enable them to approach the more transcendent aspects of reality. In a similar way the eland antelope played a central symbolic role for the San, being ritually employed as meat and fat, in mime, and as concept and image. The eland appears in ritual dances, marriage ceremonies and shamanic practices involving rock paintings. Lewis-Williams (1998:88) suggests that the eland can be regarded as a 'key symbol' because it lies at the heart of the San belief system, and so has diverse associations evoking a wide 'semantic spectrum'. It is polysemic rather than having a single meaning.

However, once a key symbol has been marked on to a rock surface during a ritual, then the notion of polysemy is no longer helpful. Understanding its context becomes much more critical for a successful de-coding of an image's meaning. For the San, for example, Lewis-Williams argues that

"[I]t is wrong to assume that a painting of an eland is the polysemic symbol. On the contrary, a painting of an eland is one contextualized manifestation of the abstract symbol, and, as such, it will have a restricted rather than a diffuse semantic focus." (Lewis-Williams 1998:89).

When a key symbol has been manifested as an image, its context in sacred space and ritual time generates powerful indexical meanings which, to onlookers, probably take precedence over the symbol's wider associations. In the case of rock art, because the image has become an enduring mark on the cultural landscape, its presence strengthens memories and reinforces the cosmic ideas that myths express and rituals legitimate. At the same time, the motifs of rock art are themselves powerful visual metaphors that give symbolic expression to ideas that could never be conveyed so effectively by the spoken word alone. Therefore as icon, index and symbol, we can expect the principal motifs of the Padjelanta engravings to be rich in cultural meanings.

\section{Sámi iconography}

Unfortunately testing these ideas against Sámi ethnography is not straightforward. As already discussed, we have only a sparse record of Sami ritual practices, and the same is true of Sámi iconography. With a few exceptions like the Padjelanta images, almost the only aspect to have survived from pre-Christian times are the figures on 72 drums (Manker 1950). Before the $18^{\text {th }}$ century Sámi drums were used in the context of divination rituals and also by the shamans (noajdde) for trance. Although the figures that cover the drum-skins are regarded today as expressions of shamanic beliefs about the cosmos, in most cases their precise meaning is unclear (Rydving 1993). However, it is generally agreed that the drums show the world of the shaman to be divided into three sections representing the heavenly, the everyday and the subterranean spheres of Sámi cosmology: "the different spheres are populated by gods, goddesses and other supernatural beings, as well as by humans and animals" (Westman 1997:40). 
Sámi beliefs about the soul were linked to this concept of worlds that were populated by deities with particular names and special roles, and specific connections to sacred places in the landscape. However, the object of worship at such places was the power that resided within nature and its elements, as personified by gods and spirits, rather than the actual rocks and lakes, the animals, the wind or the thunder (Mulk 1994b). Sámi myths can provide us with insights into this cosmic world, and also release us from the need to base prehistory entirely on local sources, as we have good reason to believe that the mythical world of different Finno-Ugrian peoples contains many shared elements with strong continuities in time and space.

\section{SÁMI MYTHS}

\section{Myths about hunting animals}

Sámi myths show us that no sharp distinctions were drawn between the living and the dead, between the visible and the invisible, or between people, animals and plants. Mankind was not seen as superior to the animal world, while the animals had their own lives, afterlives and souls. People and animals were transmutable, as reflected in stories where animals turn into humans, or where men, women or children turn back into animals (Edsman 1965). The Kola Sámi, for example, have only a few stories with only animal characters. More often animals work in connection with humans, and there are many myths which include humans transforming into bears, wolves or wild reindeer (Kharuzin 1890, cited by Sergejeva 2000:164-5).

Acknowledging these realities meant that hunting and killing animals was spiritually meaningful and, necessarily, was surrounded by ritual. As Hultkrantz (1965:303) suggests 'the boundary line between the concrete animal and the spirit animal is, indeed, very floating'. Bear hunting beliefs and rituals provide a good example. In Sámi beliefs recorded in the historical period, the bear is considered to be God's dog and a messenger between gods and humans in the different worlds. In a well-known Sámi myth a male bear has taken a woman to be his wife. She bears him a son, whereupon the bear, when his time comes, allows himself to be killed by her brothers. But before the bear dies he gives the woman instructions on how his body and skeleton must be treated if the humans are to have dominion over him. He asks to be buried with special rites and ceremonies. Similar bear stories and similar rituals showing respect to bears are found in other cultures in the circumpolar area, and other animals have also been the object of similar beliefs and ceremonies (Fjellström 1981:13-15; Bäckman 1981:43-46).

Across the entire circumpolar region it seems likely that the bear has been regarded as a sacred animal over a long period of prehistory. At Alta in Finnmark there are depictions of bear hunting and, in two separate instances, pictures showing in extraordinary detail the bear's seasonal pattern of activities. The art is dated to the period 4200-3600 BC, and it strongly suggests symbolic connections between the bear, reindeer, human hunters and the underworld (Helskog 1999). Bear graves, where the bones of hunted animals were reassembled and ritually interred, are also known archaeologically. The oldest example in northern Sweden is from Vägvisarholmen, in the foothills zone of Sirkas sameby, which dates from the $10^{\text {th }}$ century $A D$, while an 
example from Kjaerfjord in north Norway dates from around the $3^{\text {rd }}$ century AD (Mulk 1994a:115; Myrstad 1996:74).

\section{The Mandasj myth}

Another important myth concerns Mandasj (English, Myandash). The stories derive from the eastern part of the Kola peninsula and were first recorded in 1873 . Several versions of the story were recorded by the Soviet ethnographer V. Charnoluski in the 1920s. He believed that the myths of Mandasj could be remnants of an ancient Sami epic that had been jointly recited or sung at clan gatherings. In Kola there were still special places where sacrifices to Mandasj were made, for example next to a lake named Akkajavr ('the grandmother's lake'). At this site Charnoluski found a pile of stones of different sizes, and around them were reindeer antlers, some decorated with red cloth and pearl shell. By offering the antlers to Mandasj the people hoped for good hunting (Charnoluski 1966:308, cited by Ernits 1999:40).

Ernits $(1999,2000)$ has recently provided an overview of 29 recorded versions of the Mandasj myth. In 22 versions the land of Mandasj is regarded as the land of the Sámi forefathers, but it is a primordial world without the divisions shown on the drums between heaven, earth and underworld. There are no shamans either in the world of the Mandasj myth. Instead we have two parallel worlds, Mandasj's world and the human world. Between the two worlds flows a river of blood, the Mandasj river, whose waves consist of lungs and the stones of livers. These two worlds provide the context for the Mandasj myth, which we summarise from Eidlitz Kuoljok (1993:8f).

For those who live in the Mandasj-world it is easy to get across the river. For those who live in the humans' world it is difficult, but even humans can get across the river. They can either do it with great effort by wading across, or they can, through wisdom and cunning, influence the flow of the river. The Mandasj-reindeer came from the Mandasj-world. He was a white reindeer with golden antlers. Mandasj wanted to marry a human from the human world, and his mother helped him. She herself, in some versions of the story, was a wise old woman who had taken the shape of a reindeer cow and had dallied with antlered animals, becoming pregnant. Her son Mandasj grew up not feeding on grass and lichen, but instead hunting for his food.

Mandasj's mother sent for the oldest of three sisters to marry her son, but this sister failed to cross the river of blood. So too did the middle sister. The younger sister fared better. She got across the river by chewing the bark of the sacred alder tree and spitting its red juice into the river, and by chanting a song. Mandasj and the youngest sister married, had children and lived happily, but she had to keep one promise. She had to make sure the reindeer-skins in the tent (goahti) were not contaminated by human urine. If the skins did become wet they should not be hung out to dry or put back in the tent again. The wife tried to be careful, but one day it happened that a reindeer-skin became contaminated, and the Mandasj-reindeer/husband was turned back into an animal and thereafter could not resume his human form again. The woman remarried an ordinary human, but they had difficulties in hunting and catching enough animals to survive. The Mandasj-reindeer felt sorry for his former wife, and promised to allow 
her new husband to shoot and kill him, so that they would be able to support themselves in the future.

As in the bear myth, we see in these stories a distinctive attitude towards animals and the worlds that they occupy. The hunters' attitude to the animal that he kills is characterised by a respect for a being of equal value who, like a human, carries a soul. Through the myths and ceremonies different realities and different worlds can be brought together, and they can be reconciled. Undoubtedly the autumn sacrifices recorded in historical times among Sámi reindeer herders were a survival of the ritual practices of the earlier hunting society, and one focus for such rituals could have been the Padjelanta site.

\section{The iconography of Mandasj}

There are several important motifs in the Mandasj myth which are easily visualised and might have lent themselves to depiction. Some of these elements have been identified by scholars as being present in rock art. For example, one of the sisters in the story tried to cross the river by swimming like an otter. This motif, which matches the mythic status of otters elsewhere in the Finno-Ugrian tradition, could be represented in a huge petroglyph of an otter at Besoc Nos on Lake Onega (Ernits 1999:41).

Apart from Mandasj himself, perhaps the most important themes in the myth are Mandasj's mother as an origin figure, and secondly the river of blood. In the stories the river of blood separates the land of mortals and the mythical reindeer land. It also functions as a border between the realm of the dead and that of the living, between companions and ancestors (Ernits 1999: 40). Among the Nganasans of the Taimyr peninsula rivers are still conceptualised as the veins of Mother Earth, suggesting that at a deeper symbolic level we might be able to conflate Mandasj's mother and the river of blood into an all-embracing notion of the Earth Mother (Eidlitz Kuoljok 1993:9f). The Nganasan representation of the Earth Mother figure is not through an abstract sign, but is instead an iconic likeness to a real woman (Eidlitz Kuoljok 1999:159).

Several Russian scholars have interpreted petroglyphs from the Kola region and Lake Onega as depictions of motifs from the Mandasj myths (Ernits 1999: 32). The same connection has been made by Eidlitz Kuoljok (1993:7; 1999) in her interpretation of some of the figures from Alta fjord, north Norway. The images in question are from Amtmannsnes II near Alta, where Helskog $(1987,1988)$ has documented a large number of figures of humans and animals that can be dated to the period 2700-1700 BC. Alongside numerous reindeer there are stylized anthopomorphic figures, each shown as different in size and appearance as if representing a particular god or goddess. Some seem to be pregnant. One is a dancing figure with what seems to be a reindeerantler on its head. Long zig-zag lines, possibly rivers, connect different figures across the rock. Helskog (1988) and Autio (1991) both consider it likely that the panel shows mythological events depicted in connection with religious rituals, rather than ordinary human beings or historical events. Eidlitz Kuoljok (1993:7) suggests that the biggest figure on the left side of the composititon is a depiction of the mother of Mandasj giving birth to a reindeer calf, alongside the river of blood (Figure 7). 


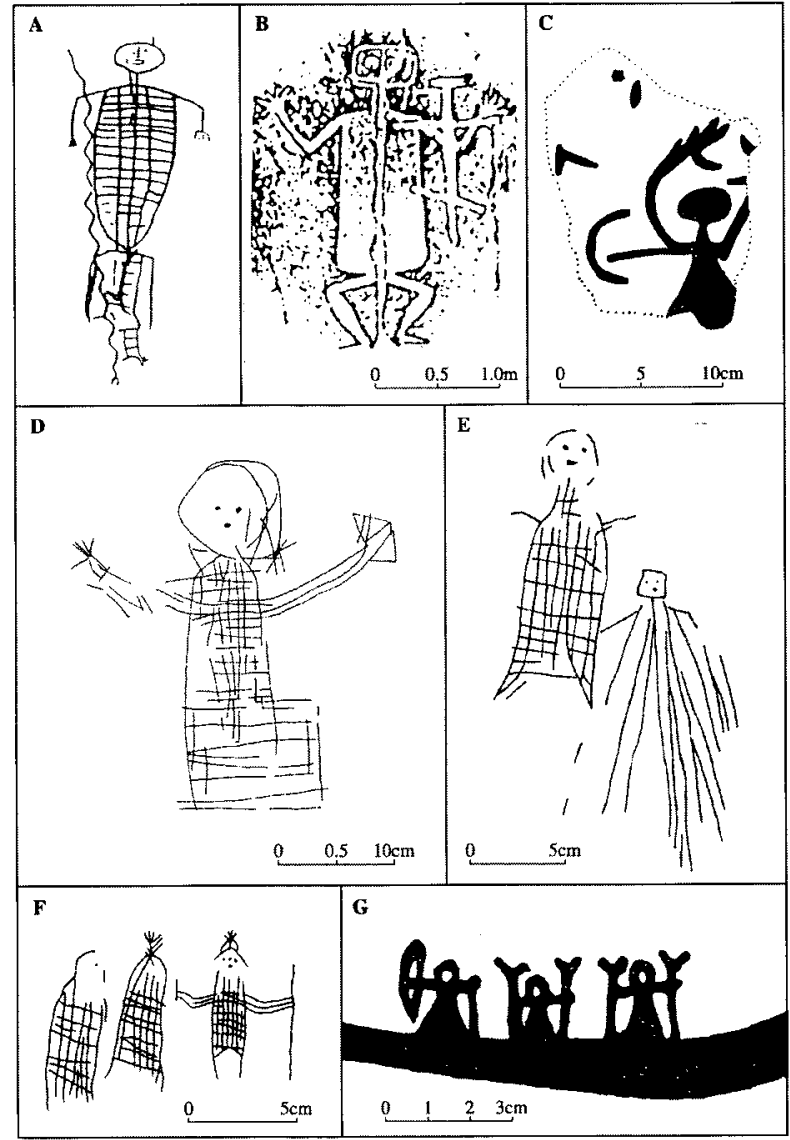

Fig. 7. Some comparisons between anthropomorphic images from different parts of the Sami region (all are drawn at different scales):

$A$. The largest anthropomorph from Amtmannsnes II, Alta, north Norway; dated to the period 2700-1700 BC (Helskog 1988:66-7), which Eidlitz Kuoljok (1993, 1999) suggested represents the mother of Mandasj.

$B$. A very large anthropopomorph from Besoc Nos, Lake Onega, which Ernits (1992:119) suggested is an image of Máttaráhk ka dating from the Viking Age or Medieval period.

C. Anthropomorph engraved on a quartzite stone with a metal tool, excavated from the Inland Sami settlement at Ahutjvagge, Langas, northern Sweden, and dating from either Iron Age, Viking Age or Medieval periods, and tentatively identified as an image of Juoksáhkká (redrawn after Mulk 1985:439).

$D, E$ and F. Phase I anthropomorphs from the Padjelanta site.

$G$. Painted figures on the skin of a 17th century Lule Sámi drum, Drum 52 of Manker (1950), which he identified as representing the three daughters of Máttáráhkká, namely Sáráhkká, Juoksáhkká and Uksáhkká (Manker 1950:4l4, motifs 64.39. 64.38 and 64.37).

\section{Mandasj's mother $=$ Máttaráhkká = Padjelanta anthropomorphs?}

If the Mandasj myth was widespread in the Sámi world in hunting times, and if it had the primordial significance that some scholars have claimed, then the mother of Mandasj becomes a key figure. As an Earth Mother symbol, she would appear to occupy an identical position to Máttaráhkká in the pantheon of Sámi deities recorded in northern Scandinavia in Early Modern times. There is actually an intriguing linguistic connection, as the name 'Mandasj' is a diminutive form of 'Máttaráhkká' (Olavi Korhonen, pers. comm.). It is therefore not unreasonable to suggest that the origin figure who gave birth to Mandasj in the myths could be the same figure represented in the large anthropomorph depicted at Amtmannsnes at Alta, even though the suggestion implies a remarkably extended continuity of ideas. If we can make this correlation, then it matters not whether she symbolises Mandasj's mother, or Máttaráhkká, or some other Earth Mother figure. In either case she would be a figure of prime importance in a range of religious contexts. 
For the Sámi the primordial, original or first mother Máttaráhkká was a mother goddess with multiple qualities (Fellman 1906; Ränk 1949; Bäckman 1982). Some of Máttaráhkkás different aspects were represented in the earthly sphere by her three daughters Sáráhkká, Juoksáhkká and Uksáhkká. She might also be seen as the goddess of death, Jábmeáhkká. Together these deities symbolised the cosmic force that created life and ended it. Máttaráhkká therefore represented the forefathers and foremothers of the Sámi people as well as their belief in reincarnation.

Máttaráhkká had the capacity to intervene in people's everyday lives. According to Sámi informants interviewed in northern Finland around 1830, she could retrieve lost objects, she could help someone lost in the forest, and she could restore sight to the blind and hearing to the deaf (Fellman 1906:119ff). Sacrifices to her were made at a special altar, which consisted of three smooth stones of different sizes that were placed on level ground. Appropriate offerings were either a female wild reindeer, or a male goat, or a male sheep (Fellman 1906:121). Oral histories from Tanajoki in Sombio in the north of Finland include the words of a song that was sung to Máttaráhkká by women while they were kneeling (Myrhaug 1997:86):

(in Sámi, 1906 text)

Mon läm maderest

Ja madem mon bådcem

Madarakkost mon läm ällam

Ja madeakko kuulvi mon bådam (in English translation)

From mother I am

and to mother I come

By Máttaráhkká I have lived

and to the realms of Máttaráhkká I go

This song reveals many of the different qualities of Máttaráhkká as an Earth Mother figure. We believe she is the primordial woman who, in a different guise, is represented as the mother of Mandasj in the myths.

\section{The iconography of Máttaráhkká}

In contrast to the folklore, however, the iconographic evidence for Máttaráhkká is much more sparse. Images of her three daughters are thought to be depicted on some of the Sámi drums of the $17^{\text {th }}$ and $18^{\text {th }}$ centuries (see Figure 7), although this identification is retrospective and was not revealed by contemporary Sámi informants (Rydving 1991). However, the Earth Mother herself seems not to be depicted in Sámi ethnographic material. Indeed, despite her manifold qualities Máttaráhkká does not really provide any obvious iconic signifiers. What aspect of her appearance could an artist select as being distinctive?

Ernits (1992) has pointed to Máttaráhkká's ability to see in darkness, which Fellman (1906: 120) recorded as a Sámi belief in northern Finland. Seeing in the dark was also a feature of the Mothers of the Earth of various Siberian peoples (Itkonen 1944). Using this clue, Ernits suggests we can identify Máttaráhkká among the rock engravings at Besoc Nos on Lake Onega (Figure 7). She is depicted there as a very large ( $2.46 \mathrm{~m}$ high) anthropomorphic figure with prominent round eyes, and with legs that straddle a natural crack in the rock (Ernits 1992:118-121).

At Padjelanta some of the anthropomorphs are also relatively large (up to $0.3 \mathrm{~m}$ ) 
and they are depicted, without exception, as having eyes. They stare out of the rock, looking southwards. We suggest it makes sense to identify these figures as representations of the same Earth Mother figure (Mandasj's mother, or Máttaráhkká), a cosmic power which embodied the earth and its material production, and whose help was therefore acknowledged in a range of contexts - for example, hunting reindeer, taking soapstone from the earth, or consigning the dead to the underworld.

\section{CONCLUSION}

We therefore suggest that, on the balance of evidence, the Padjelanta anthropomorphs should be interpreted as depictions of Máttaráhkká. She is the cosmic power that is represented on Sámi drums in the image of her three daughters, and, following Eidlitz Kuoljok (1993), we suggest that the same Earth Mother figure appears in the Alta rock art and, in mythical form, as the mother of Mandasj. There are two strands to support this argument: iconographic resemblance, and ritual context.

The iconography does indeed show some resemblances, although by itself this would not be a sufficient argument. However we do point to some similarities between the drum figures of Máttaráhkká's daughters, the Earth Mother figures at Amtmannsnes II, and the various Padjelanta anthropomorphs. Their large feminine bodies, standing posture, round heads and staring eyes, cross-hatched clothing, and out-stretched arms are aspects which, taken together, do constitute a notable resemblance (Figure 7).

What these figures also have in common is their context. Alta is accepted as the centre for hunting ceremonial and shamanic ritual, with the rock art playing a part in commemorating or reinforcing that function (Helskog 1999). Similarly, we have argued that whether its prime importance was for hunting, burials or quarrying, Padjelanta was a distinctive location, a sacred site and the focal point of the mountain plateau region. It seems entirely likely that an Earth Mother figure would be at the centre of rituals that were carried out there, rituals that were confirmed by images on the rock. For a group of Sámi hunters visiting the site the combination of signifiers, both ecological, ritualistic and iconographic, would have reinforced cosmic meanings and reaffirmed the group's cultural identity.

\section{ACKNOWLEDGEMENTS}

For their participation in their fieldwork at the Padjelanta site in 1992, 1993, 1998 and 1999, we thank in particular Lennart Lundquist, Irene Partopuoli, Tomas Partopuoli and Anders Lindberg. For financial assistance we are grateful to Ajtte Museum, the Göran Gustafsson Foundation. St John's College, Cambridge, and the Scandinavian Studies Fund of Cambridge University. For valuable discussion and comments during the preparation of this paper we thank Chris Chippindale, Birgitta Edeborg, Knut Helskog, Kerstin Eidlitz Kuoljok, Neil Price, Inger Zachrisson and Anna Westman. A shorter version of this paper was presented at the $9^{\text {th }}$ Finno-Ugrian Congress in Tartu, Estonia, in August 2000. We are grateful to the congress organisers, and in particular to Mare Koiva and Andes Kuperjanov of the Folk Belief and Media Group of the Estonian Literary Museum, for their hospitality and assistance. 


\section{REFERENCES}

Autio, E. 1991. The snake and zig-zag motifs in Finnish rock paintings and Saami drums. In: T. Ahlbäck \& J. Bergman (Eds). The Saami Shaman Drum. Scripta Instituti Donneriani Aboensis XIV. Pp. 52-79. Stockholm: Almqvist \& Wiksell.

Bayliss-Smith, T.P. \& Mulk, I.M. 1998. Segelbåtar i Padjelanta. Sámiska hällristningar från järnålder och medeltid i Laponia, Lappland. In: Människor och båtar i Norden (Sjöhistorisk Årsbok 1998-1999). Pp. 39-51. Stockholm: Föreningen Sveriges Sjöfartsmuseum.

- 1999. Sailing boats in Padjelanta: Sami rock engravings from the mountains in Laponia, northern Sweden. Acta Borealia 16 (1). Pp. 3-4l.

Bell, C. 1997. Ritual. Perspectives and Dimensions. New York: Oxford University Press.

Borgos, J. I. \& Torgvaer, T. 1998. Samer og båtbygging. In: Människor och båtar i Norden (Sjöhistorisk Årsbok 1998-1999). Stockholm: Föreningen Sveriges Sjöfartsmuseum. Pp. 104-115.

Burks, A. 1949. Icon, index and symbol. Philosophical and Phenomenological Research 9: 673-689.

Bradley, R. 2000. An Archaeology of Natural Places. London: Routledge.

Bäckman, L. 1981. Kommentar till Pehr Fjellströms skildring av samernas björnjakt och björnriter, 'Kort berättelse samt deras der wid brukade widskeppelser' 1755. Norrländska_skrifter (Umeå) 5. Pp. 4363.

- 1982. Female - divine and human. A study of the position of the woman in religion and society in northern Eurasia. In: $\AA$. Hultkrantz \& Ø. Vorren (Eds). The Hunters, their Culture_and Way of Life. Pp. 143-162. Tromsø, Oslo, Bergen: Universitetsforlaget.

Charnoluski, V. 1966. O kul'te Miandasha. Skandinavski sbornik, Tallinn. Pp. 301-315.

Deacon, T. 1997. The Symbolic Species. The Co-Evolution of Language and the Human Brain.London: Penguin.

DuBois, T.A. 1999. Nordic religions in the Viking Age. Philadelphia: University of Pennsylvania Press.

Edsman, C.M. 1965. The hunter, the games and the unseen powers. Lappish and Finnish bear rites. In: H. Hvarfner (Ed). Hunting and Fishing. Pp. 159-188. Luleă: Norrbottens Museum.

Eidlitz Kuoljok, K. 1993. Den vilda renen i myt och rit. Jokkmokk: Ájtte förlag.

- 1999. Moder jord och andra mödrar: Föreställningar om verkligheten bland folken i norr och vår syn på den. Stockholm: Carlssons bokförlag.

Eliade, M. 1963. Myth and Reality, translated by W.R. Trask. New York: Harper \& Row.

Ernits, E. 1992. The purpose and content of the petroglyphs in the Onega region. In: M. Hoppál and J. Pentakäinen (Eds). Northern Religions and Shamanism. Pp. 115-124. Budapest: Akademiai Kiado; and Helsinki: Finnish Literature Society.

Ernits, E. 1999-2000. Folktales of Meandash, the mythic Sami reindeer, Parts I and II. Folklore, Electronic Journal of Folklore, <http//:haldjas.folklore.ee/folklore>. Printed version: Institute of Estonian Language, Tartu. Vol. 11. Pp. 31-59; and vol. 13. Pp. 66-92.

Fellman, J. 1906. Avteckningar under min vistelse i Lappmarken, 4 vols. Helsingfors (Helsinki): Finska litteratursällskapets tryckeri.

Firth, R. 1973. Symbols Public and Private. London: Allen \& Unwin.

Fjellström, P. 1981. Kort Berättelse om Lapparnes Björna-fänge Samt Deras derwid brukades widskeppelser, 1755. Umeå: Två Förläggare Bokförlag.

Hansen, L.I. 1990. Samisk fangsstsamfinn og norsk hovdingøkonomi. Oslo: Novus forlag.

Helskog, K. 1987. Selective depictions. A study of 3,500 years of rock carvings from Arctic Norway and their relationship to the Sámi drums. In: I. Hodder (Ed). Archaeology as Long-term_History. Pp. 1730. Cambridge: Cambridge University Press.

- 1988. Helleristningene i Alta: Spor etter Ritualer og Dagligliv i Finnmarks Forhistorie. Alta: Alta Museum.

- 1999. The shore connection. Cognitive landscape and communication with rock carvings in northernmost Europe. Norwegian Archaeological Review 32 (2). Pp. 73-94.

Hultblad, F. 1968. Övergång från nomadism till agrar bosättning i Jokkmokks socken. Acta Lapponica 14, Nordiska museet. Stockholm: Almqvist \& Wiksell/Gebers. 
Hultkrantz, $\AA$. 1965. Types of religion in the Arctic hunting cultures. A religio-ecological approach. In: H. Hvarfner (Ed). Hunting and Fishing. Pp. 265-318. Luleå: Norrbottens Museum.

- 1985. Reindeer nomadism and the religion of the Saamis. In: L. Bäckman \& $\AA$. Hultkrantz (Eds). Saami Pre-Christian Religion. Studies of the Oldest Traces of Religion among the Saamis. Pp. 11-28. Stockholm: Almqvist \& Wiksell.

Itkonen, T.I. 1944. Suomen lappalaistet muinaisuskosta. Kalevalseuran vuosikirja 23-24. Pp. 60-74.

Kharuzin, N. 1890. Russkiye lopari. Izvestiya Russkogo Imperatorskogo obshchestva lyubiteley yestestvoznaniva, antropologii i etnografii LXVI. Trudy Etnograficheskogo otdela 10. Moscow.

Kolsrud, K. 1961. Sommersete. Til problemet om halvnomadisme og seterflyttning blant norske sjøsamer. In: A. Nesheim (Ed). Sámiske samlinger 5. Pp. 1-74. Oslo: Norsk Folkemuseum.

Klassen, M.A. 1998. Icon and narrative in transition: contact-period rock-art at Writing-On-Stone, southern Alberta, Canada. In: C. Chippindale \& P.S.C. Tacon (Eds). The Archaeology of Rock-Art. Pp. 42-72. Cambridge: Cambridge University Press.

Kleppe, E.J. 1974. Samiske jernaldersstudier ved Varangerfjorden. Magistergradsavhandling, Universitetet i Bergen (unpublished).

Lewis-Williams, J.D. 1981. Believing and Seeing. Symbolic Meanings in Southern San Rock Paintings. London: Academic Press.

- 1985. Testing the trance explanation of southern African rock art: depictions of felines. Bolletino del Centro Camumo di Studi Preistorici 22. Pp. 47-62.

- 1998. Quanto? The issue of 'many meanings' in southern African San rock art research. The_South African Archaeological Bulletin 53 (168). Pp. 86-97.

Lund, N. (Ed). 1984. Two Voyagers at the Court of King Alfred. The Ventures of Ohthere and Wulfstan together with the Description of Northern Europe from the Old English Orosius. York: William Sessions.

Manker, E. 1950. Die Zaubertrommel II. Die Trommels als Urkunde Geistigen Leben. Acta Lapponica 6. Stockholm: Nordiska museet.

Mebius, H. 1965. Sacrificial cult and hunting rites: some views on Same religion. In: H. Hvarfner (Ed). Hunting and Fishing. Pp. 351-362. Luleå: Norrbottens Museum. Reprinted 1969, Offerkult och jakriter. In: Norrbottens läns hembygdsföreninggs årsbok 1970. Pp. 61-68. Luleå: Norbottens museet.

- 1968. Värro. Studier i samernas förkristna offerriter: Stockholm: Almqvist \& Wiksell.

Moe, D. 1991. Hustad, Arstad and Naurstad. A vegetational study of three farms in Salten, North Norway. Norsk Geografisk Tiddskrift 45. Pp. 11-24.

Molyneaux, B. 1987. Concepts of humans and animals in post-contact Micmac rock art. In: H. Morphy (Ed). Animals into Art. Pp. 193-214. London: Unwin Hyman.

Mulk, I.M. 1985. The wild reindeer hunt and associated ceremonial symbols. In: In Honorem Evert Baudou. Archaeology and Environment 4. Pp. 435-441. Umeå: Department of Archaeology, University of Umeå.

- 1994a. Sirkas - ett Sámiskt fångstsamhälle i förändring Krff. - 1600 e.Kr: Umeå: Studia Archaeologica Universitatis Umensis 6.

- 1994b. Sacrificial places and their meaning in Saami society. In: D. Carmichael, J. Hubert, B. Reeves \& A. Schanche (Eds). Sacred Sites, Sacred Places. Pp. 121-131. London: Routledge.

- 1996. The role of the Sámi in fur trading during the Late Iron Age and Nordic Medieval period in the light of the Sámi sacrificial sites in Lapland, northern Sweden. Acta Borealia 13. Pp. 47-80.

- 1998. Nyfunna hällristningar avbildar Sámiska segelbåtar. Populär Arkeologi 16 (4). Pp. 23-25.

Mulk, I.M. \& Bayliss-Smith, T.P. (in press) Coins in Sámi sacrificial sites: religious ritual, social organisation and the fur trade in northern Sweden, c. 800-1200 A.D. In: K. Bornholdt \& I. Wood (Eds). Gods, Graves and Numismatics. Leiden: Brill.

Mulk, I.M., Bayliss-Smith, T.P. \& Nordqvist, L. 2001. Rapport över dokzmentationer av hällristningar från järnålder och medeltid i Padjelanta. Jokkmokks sn., Lappland. Ájtte, Svenskt Fjäll- och Samemuseum, Jokkmokk.

Myrhaug, M.L, 1997. I modergudinnans fotspor. Sámisk religion med vekt på kvinnelige kultutovere og gudinnekult. Oslo: Pax Forlag A/S. 
Myrstad, R. 1996. Bjørnegraver i Nord-Norge. Spor etter den Sámiske bjornkulten. Huvudoppgave i arkeologi, Institutt for samfunnsvitenskap, Universitetet i Tromsø.

Nielssen, A.R. 1990. Fra steinalderen til 1700-talet. Lødingen, Tjeldsund og Tysfjords historie 4. Bodø.

O'Meadhra, U. 1993. Viking-Age sketches and motif-pieces from the northern earldoms. In: C.E. Batey, J. Jesch \& C.D. Morris (Eds). The Viking Age in Caithness, Orkney and the North Atlantic. Pp. 423440. Edinburgh: Edinburgh University Press.

Rappaport, R.A. 1979. Ecology, Meaning and Religion. Richmond, California: North Atlantic Books. - 1999. Ritual and Religion in the Making of Humanity. Cambridge: Cambridge University Press.

Rowlands, M. 1993. The role of memory in the transmission of culture. World Archaeology 25. Pp. 141 151.

Rydving, H. 1991. The Saami drums and the religious encounter in the $17^{\text {th }}$ and $18^{\text {th }}$ centuries. In: T. Ahlbäck \& J. Bergman (Eds). The Saami Shaman Drum. Scripta Instituti Donneriana Aboensis 14. Pp. 28-51. Åbo, Finland: Donner Institute.

- 1993. The End of Drum-Time. Religious Change among the Lule Saami, 1670s-1740s. Uppsala: Acta Universitatis Upsaliensis, Historia Religion 12.

Ränk, G. 1949. Kysymys lapin Madderakan ja hänen tyttuariensä alkuperästä. Kalevalaseuran vuosikirja 29. Pp. 180-247.

Schanche, K. 1988. Mortensnes, en boplass i Varanger: En studie av samfunn og materiell kultur gjennom 10.000 arr: Magistergradsavhandling i arkeologi, Universitet i Tromsø (unpublished).

Schanche, A. 1997. Graver i ur och berg. Samisk gravskikk og religion 1000 f.Kt: til 1700 e.Kr. Avhandling til doktor artium, Universitet $\mathrm{i}$ Tromsø.

Sergejeva, J. 2000. The research history of Kola and Scolt Sami folklore. In: J. Pentakainen (Ed). Sami Folkloristics. Pp. 155-188. Turku: Nordic Network of Folklore.

Serning, I. 1956. Lapska offerplatsfynd från järnålder och medeltid $i$ de svenska lappmarkerna. Acta Lapponica 11. Stockholm: Nordiska museet.

Simonsen, P. 1969. Ny bergkunst fra Finnmark. Ottar 1969-3, Tromsø Museum, Nr. 61. Pp. 12-19.

- 1970. Fortidminner nord for polarsirkelen. $2^{\text {nd }}$ edn. 1991. Oslo: Universitetsforlaget.

- 1979. Veidemenn på Nordkalotten. Stensilserie. Universitet i Tromsø. B-historie 3. Pp. 363-514.

Storli, I. 2000. 'Barbarians' of the North: reflections on the establishment of courtyard sites in North Norway. Norwegian Archaeological Review 33. Pp. 81-103.

Tacon, P.S.C., Wilson, M. \& Chippindale, C. 1996. Birth of the rainbow serpent in Arnhem Land rock art and oral history. Archaeology in Oceania 31. Pp. 103-124.

Tambiah, S.J. 1979. A performative approach to ritual. Proceedings of the British Academy 65. Pp. 113169.

Tylor, E. 1871. Primitive Culture. London: Murray.

Westerdahl, C. 1987. "Et sätt som liknar them uti theras öfitga lefnadsart". Om äldre samiskt bãtbvgge och samisk båthantering. Umeâ: Skrifter utgivna av Johan Nordlander-sällskapet, Nr. 11.

Westman, A. 1997. The sun in Sami mythology. Acta Borealia 14 (2). Pp. 31-58.

Vastokas, J.M. 1990. Landscape as experience and symbol in Native Canadian culture. In: J. Vastokas (Ed). Perspectives of Canadian Landscape: Native Traditions. Pp. 55-82. North York, Ontario: Robarts Centre for Canadian Studies, York University.

Vorren, K.D., Nilssen, E. and Mørkved, B. 1990. Age and agricultural history of the '-stadir' farms of North and Central Norway. Norsk Geografisk Tiddsskrift 44. Pp. 79-102.

Zachrisson, I. 1987. Siele sacrifices, Odin treasures, and Saami graves? In: T. Ahlbäck (Ed). Saami Religion. Pp. 61-68. Stockholm: Almqvist \& Wiksell. 